IZA DP No. 8686

Human Trafficking in Southeast Asia:

Results from a Pilot Project in Vietnam

Ngan Dinh

Conor Hughes

James Hughes

Margaret Maurer-Fazio

November 2014 


\title{
Human Trafficking in Southeast Asia: Results from a Pilot Project in Vietnam
}

\author{
Ngan Dinh \\ Cambridge University
}

Conor Hughes

NBER

\section{James Hughes}

Bates College

\section{Margaret Maurer-Fazio \\ Bates College and IZA}

\section{Discussion Paper No. 8686 \\ November 2014}

\author{
IZA \\ P.O. Box 7240 \\ 53072 Bonn \\ Germany \\ Phone: +49-228-3894-0 \\ Fax: +49-228-3894-180 \\ E-mail: iza@iza.org
}

\begin{abstract}
Any opinions expressed here are those of the author(s) and not those of IZA. Research published in this series may include views on policy, but the institute itself takes no institutional policy positions. The IZA research network is committed to the IZA Guiding Principles of Research Integrity.

The Institute for the Study of Labor (IZA) in Bonn is a local and virtual international research center and a place of communication between science, politics and business. IZA is an independent nonprofit organization supported by Deutsche Post Foundation. The center is associated with the University of Bonn and offers a stimulating research environment through its international network, workshops and conferences, data service, project support, research visits and doctoral program. IZA engages in (i) original and internationally competitive research in all fields of labor economics, (ii) development of policy concepts, and (iii) dissemination of research results and concepts to the interested public.
\end{abstract}

IZA Discussion Papers often represent preliminary work and are circulated to encourage discussion. Citation of such a paper should account for its provisional character. A revised version may be available directly from the author. 
IZA Discussion Paper No. 8686

November 2014

ABSTRACT

\section{Human Trafficking in Southeast Asia: Results from a Pilot Project in Vietnam ${ }^{1}$}

Human trafficking is one of the most widely spread and fastest growing crimes in the world. However, despite the scope of the problem, the important human rights issues at stake and the professed intent of governments around the world to put an end to "modern day slavery", there is very little that is actually known about the nature of human trafficking and those most at risk as potential victims. This is due in large part to the difficulty in collecting reliable and statistically useful data. In this paper we present the results of a pilot study run in rural Vietnam with the aim of overcoming these data issues. Rather than attempt to identify victims themselves, we rely on the form rural migration often takes in urbanizing developing countries to instead identify households that were sources of trafficking victims. This allows us to construct a viable sampling frame, on which we conduct a survey using novel techniques such as anchoring vignettes, indirect sampling, list randomization and social network analysis to construct a series of empirically valid estimates that can begin to shed light on the problem of human trafficking.

JEL Classification: J47, J61, J82, K37, K42, O15

Keywords: human trafficking, labor migration, Vietnam, household survey, indirect sampling, social network analysis, pilot study, public policy

Corresponding author:

Margaret Maurer-Fazio

Bates College

276 Pettengill Hall

4 Andrews Road

Lewiston, Maine 04240

USA

E-mail: mmaurer@bates.edu

\footnotetext{
${ }^{1}$ We thank Toman Omar Mahmoud, Matthieu Chemin, Johannes Haushofer, Laura Hackney, Elizabeth Xiao, Mahvish Shaukat, Anna Alekseyeva and students at the Fulbright Economics Teaching Program in Ho Chi Minh City for valuable comments. The following Bates College programs all generously contributed funding to this project: the Phillips Fellowship Program, the Harward Center for Community Engagement and the Faculty Development Fund.
} 


\section{Introduction}

The large increase in domestic and international migration over the past two decades has been accompanied by a concomitant increase in human trafficking. Traffickers co-opt voluntary labor migrants into involuntary labor through fraud, debt, intimidation, coercion and force. Restrictions on legal migration have given rise to lucrative criminal networks that facilitate illegal migration. These same criminal networks are often involved with human trafficking. Many of the same forces that have increased returns to migration-globalization, enhanced transportation and communicationhave also increased the returns for criminals involved in human trafficking.

The last two decades witnessed a 50\% increase in international migrants and a greater than $500 \%$ increase in remittances to their home countries. There are over 232 million international migrants in the world today (Dumont and Hovy 2013). The higher returns to migration are easily seen in the enormous increase in remittances, which today approach a half trillion US dollars annually (Ratha, Mohapatra, and Silwal 2010). Domestic migration has experienced similar growth, as indicated by the rapid urbanization seen in most developing countries.

The dimensions, causes and characteristics of the human trafficking tragedy, however, are largely undocumented. Despite over two decades of efforts by national and local governments, the United Nations, academics, NGOs and other interest and advocacy groups, statistically reliable data on the issue are scarce. This lack of reliable data hinders almost every effort to combat human trafficking. Policymakers and researchers cannot answer many basic questions concerning the demographic, occupational, ethnic or other characteristics that might distinguish successful migrants from those more vulnerable to trafficking.

This paper has four principle objectives:

First, we review the state of data collection on human trafficking to illustrate the need for better data on human trafficking.

Second, we present our household survey methodology, which we seek to validate as a method for collecting statistically reliable data on human trafficking.

Third, we present the results of a pilot study using the household survey methodology to gather information on human trafficking in Trà Vinh Province Vietnam. These include estimates on the extent of trafficking in the region, the predictors of trafficking vulnerability and predictors of knowing trafficking victims.

Finally, we use the results of our pilot study to draw tentative suggestions for public policy. Our analysis reveals several areas that deserve more attention from governments and other interested organizations as well as areas where resources are not being deployed effectively. 


\section{Background}

\subsection{Defining human trafficking}

In addition to data collection issues, disagreement among researchers, government officials and aid organizations concerning exactly which activities constitute human trafficking have impeded the collection of data and the formulation of policy. We adopt the definition of human trafficking contained in the United Nations Protocol to Prevent, Suppress and Punish Trafficking in Persons (United Nations 2003), which defines human trafficking as the use of force, coercion, abduction, fraud or deception to exert control over another person for the purposes of exploitation.

For our purposes, human trafficking must contain the elements of coercion and exploitation. Coercion and exploitation distinguish human trafficking from human smuggling. Smugglers provide illegal transportation for migrants across international borders in return for compensation. While this transaction may indeed involve coercion, deception and exploitation, the distinction is in whether such treatment continues once the migrant is transported to the destination. Distinguishing human trafficking from human smuggling and similar activities, where possible, allows us to focus on the most egregious violations of human rights and personal dignity.

\subsection{Data deficiencies in human trafficking research}

The volume of human trafficking research has increased greatly in the past two decades. From virtually nothing in the early 1990s (Laczko and Goździak 2005), citations grew to well over 700 by 2008 (Goździak and Bump 2008). However, the quality of the data used in much of this research is suspect and deficient along a number of well-known dimensions.

The ILO estimates that 20.9 million people are in forced labor worldwide: $68 \%$ are laborers in the private economy and $22 \%$ are victims of forced sexual exploitation, with the remaining $10 \%$ in stateimposed forced labor such as certain forms of prison labor (International Labor Organization 2012). Despite the prevalence of labor trafficking, anti-trafficking policy and research has largely failed to address human trafficking as a labor exploitation or labor market issue (Shamir 2012). International trafficking policy and research has almost completely ignored the relation between migration and trafficking, targeting instead the issues of sex trafficking and the trafficking of children. Rather than adhering to recognized research methods, much of current trafficking research advocates a particular political view (Goździak and Bump 2008).

In addition to the narrow and often highly fraught political nature of the existing research, this work is hindered by the near-complete lack of systematic and reliable data. Goździak and Bump (2008) found only $5 \%$ of the more than 700 studies they reviewed used random samples. The majority of the social science or law studies used convenience sampling, and $47 \%$ of all studies were based on "unknown" samples. Eighty-three percent of journal articles on trafficking were purely qualitative analysis, and mostly published in non-peer reviewed journals. To our knowledge, the articles by 
Mahmoud and Trebesch $(2009,2010)$ are to date the only available studies of trafficking using high quality quantitative data. UNESCO initiated the Trafficking Statistics Project to examine the origin and validity of trafficking data. UNESCO summarizes the state of knowledge as follows: "When it comes to statistics, trafficking of girls and women is one of several highly emotive issues which seem to overwhelm critical faculties. Numbers take on a life of their own, gaining acceptance through repetition, often with little inquiry into their derivations" (UNESCO Bangkok ).

A serious consequence of the focus on sex trafficking is the inattention to human trafficking as a labor market issue. Current anti-trafficking policies are centered on the criminal prosecution of traffickers and the rescue, shelter and rehabilitation of the (mostly female) victims of sex trafficking. While these measures assist at least a subset of trafficking victims, the failure to acknowledge human trafficking as an extreme form of labor exploitation-typically resulting from failed migration-these policy initiatives do not address the economic, social and legal conditions in the domestic and international labor markets that create and exacerbate migrants' vulnerability to exploitation (Shamir 2012). By creating a new data set explicitly examining the linkage between human trafficking and migration in a labor market context, we believe that we have helped to demonstrate the promise and potential of labor market protections and human capital interventions as another powerful weapon in the fight against human trafficking.

\section{Study design}

\subsection{Issues in collecting human trafficking data}

The hidden nature of trafficking makes any direct, systematic surveying of individuals virtually impossible. Any statistically sound survey design must therefore rely on information collected indirectly. To date, the bulk of these indirect efforts in trafficking research fall into one of three main categories: 1) interviews of returned victims; 2) interviews of other "stakeholders" such as advocates, civil authorities, and aid workers; and 3) media reports or police blotters. We briefly address the issues with each of these data sources in turn below.

\subsubsection{Interviews with returned victims}

Returned or rescued victims are generally located through aid centers or household surveys. Recent ILO projects have attached questions for returned victims to other household surveys (International Labor Organization 2007a). Despite the appearance of a random sampling, such surveys are subject to extreme selectivity as to who is able to escape and return home, so that the results, while informative, cannot be used for extrapolation. Additionally, some surveys only interviewed women and children, further biasing results by excluding male trafficking victims (International Labor Organization 2007b). Surveying only a segment of returned victims in a household has little potential to capture a community's, or even a household's, full experience with human trafficking. 
Surveying victims located through aid agencies suffers from many of the same selectivity problems. Not only must the victim have escaped or been rescued, but they must have been eligible for enrollment in that particular aid program. Many of these programs are geared towards survivors of sexual trafficking, which again excludes victims of labor trafficking. Additionally, the victims need to select into participation in these programs rather than finding other employment or returning home immediately. Anecdotal evidence suggests that many women choose not to participate in these programs.

\subsubsection{Interviews with other "stakeholders"}

Interviews with other stakeholders such as local administrators (UNIAP 2011) are limited by the knowledge these individuals have about trafficked victims in their communities. Additionally, by definition, many of these stakeholders have vested interests of some form in the outcomes of each project, which could potentially bias results.

\subsubsection{Media and government reports}

Reliance on media or government reports, as the ILO has done in the past (International Labor Organization 2012), is also a highly selective approach. Only a subset of trafficking cases is reported to the police or appears in the media, and local and national governments have their own interests at stake when reporting human trafficking.

\subsection{Household survey}

These data issues are not unique to human trafficking, however. Researchers face similar data issues when investigating crime of all types. In the US, the two major sources of data on crime are the FBI's Uniform Crime Reports (UCR) and the Justice Department's National Crime Victimization Survey (NCVS). The UCR is based on reports from local police precincts, similar to trafficking data collected from law enforcement or aid groups. Such data are limited by the fact that many crimes are never reported to police, severely limiting the usefulness of the UCR for researching particular types of crimes.

The NCVS surveys a random sample of US households. The NCVS is used to estimate population rates of crimes not often reported to the police. Information is also gathered on the characteristics of the victims, the nature of the crime and it's impact on the household. The NCVS is considered to be a more comprehensive, reliable, and useful data set for crime research (Rennison and Rand 2007).

This survey on migration and human trafficking takes an approach similar to the NCVS. Our focus on migrants, trafficking victims and households allows us to explore the circumstances, characteristics and consequences of migration and trafficking victimization in greater detail than other studies. 
Previous household surveys of returned victims (International Labor Organization 2007a; International Labor Organization 2007b) have been limited to a few questions added to an existing survey. The household survey used by Mahmoud and Trebesch $(2009,2010)$ identified the household of a trafficking victim, but contained no information about either the victim or the trafficking crime. The household survey described below is designed to explicitly seek information on human trafficking, the characteristics of the victim, and the trafficking incident, as well as the impact of trafficking on the household. By following the example of the NCVS, we hope to validate the concept that reliable, useful information on human trafficking can be gathered easily at the household level. Such a survey is applicable in many developing countries outside of Vietnam, and we hope this can serve as a blueprint for such efforts.

The pilot survey was conducted in the Tieu Can district of Trà Vinh province in the Mekong Delta region of Vietnam. Tieu Can is a primarily rural province. Our survey was conducted in cooperation with the People's Committee of the Tieu Can district and covered 13 communes in the district, including 24 villages, surveying a total of 496 households and 2,394 individuals. Figure 1 shows a map of the surveyed area. A sampling frame was constructed using the 2009 Vietnamese census data for the region, and villages were selected randomly from this frame. Trà Vinh is not generally considered a major source province for trafficking victims, likely due to its distance from international borders.

Within villages, households are selected randomly and given a short pre-survey. Since a household could only be a trafficking source household if the household has a migrant member, we selected on migrant households to increase the number of potential source households identified. Every migrant household identified in the pre-survey was given the full survey (406 households), and a randomly selected 90 non-migrant households were given the full survey, to allow for comparisons not just between trafficked and non-trafficked migrants, but between (potentially trafficked) migrants and non-migrants.

\section{Results}

\subsection{Characteristics of source households}

In all, our survey found 38 individuals reported as trafficked. This corresponds to approximately 9.6 trafficking victims per 1,000 persons, more than three times the ILO estimate for Asia of 3 victims per 1,000 persons. Our rate is 32.8 standard errors larger than the ILO's mean estimate, 34.4 standard errors larger if one removes their estimates of state-imposed forced labor, which we do not consider here. Though the ILO describes their 2012 estimates as "conservative", this is a noteworthy magnitude of difference, made even more noteworthy by the fact that Trà Vinh is not believed to be a major source province. Characteristics of individuals and households by migration status are reported in Tables 1 and 2. 
As expected with labor migration, migrants are generally significantly younger than non-migrants; migrants have a mean age of 29.5 while non-migrants have a mean age of 36.5 (see Figure 2 for distribution). Migrant gender is almost exactly evenly split at $50.8 \%$ female and $49.3 \%$ male (vs. $46.2 \%$ female and $53.8 \%$ male for non-migrants).

\subsection{Predictors of trafficking vulnerability}

Our outcome variables of interest in this section are binary: whether or not an individual has been trafficked, and whether or not a household sent a trafficking victim. Because of the binary nature of these variables, we employ a logistic regression model. However, traditional logistic methods underestimate the probability of "rare" outcomes sch as human trafficking ${ }^{2}$. Rarity does not affect OLS, but can be a source of bias in logistic regressions. While human trafficking is a global problem, it still qualifies as a "rare" event in the statistical sense. Therefore we correct our estimates using the rare events logistic regression model of King \& Zeng (King and Zeng 2001b; King and Zeng 2001a), and report these results along with those of the traditional logistic model. Additionally conditional logistic regressions were run to include village level fixed effects (Chamberlain 1980) ${ }^{3}$. Standard errors are clustered at the village level, and use White's correction for heteroskedasticity (MacKinnon and White 1985) ${ }^{4}$.

Despite the relatively small size of the pilot study, a number of interesting results were found. Our main regression specifications are presented in Table 3.

The sex of the victim is believed to be a major driver of trafficking risk. Women are generally believed to be at greater risk of being trafficked, primarily because of the historical policy focus on sex and marriage trafficking. In the wider context of trafficking as failed migration, we noted earlier that migrants in our sample are approximately evenly divided by sex. In none of our regression specifications is sex remotely significant ( $t$-statistics between -0.19 and 0.08 ). In fact, if anything, male migrants are marginally more likely to be trafficked than female migrants: $49 \%$ of migrants are men, yet they constitute $53 \%$ of trafficking victims.

Income is also believed to be a significant determinant in trafficking risk, though there is no consensus on the exact modality. On the "supply side" of trafficking victims, migration generally benefits households in the form of remittances. Poorer households might be willing to take more risks, or

\footnotetext{
"Rare" here does not imply rare in an absolute sense, but relative to the dataset. For example, a dataset with 100,000 observations, where only 1,000 observations see the event realized, would be considered rare. On the other hand, a dataset with only 50 observations where the event is realized in 25 instances would not be considered rare.

${ }^{3}$ In data organized into $\mathrm{G}$ groups with $\mathrm{N}$ observations per group, the unconditional maximum likelihood estimation of group fixed effects suffers from incidental parameters bias, which can become quite significant for a set $\mathrm{N}$ as $\mathrm{G}$ increases. Conditional logistic regression eliminates this bias by conditioning each individual contribution to the likelihood function on the sum of measures within each group, which removes individual level parameters from the likelihood function. As we have multiple cases where $\mathrm{G}$ (equal to 24 in this case) is greater than the number of households sampled in the village, we use conditional logistic regression when estimating fixed effects models.

${ }^{4}$ Regressions clustering at the household level yield similar results and are not presented here. When clusters are nested, as in this case where households are nested within villages, it is recommended to cluster standard errors at the higher level, in our case the village (see Cameron, Gelbach, and Miller 2011 and Pepper 2002 further discussion).
} 
be unable to afford the rate of a legitimate labor contractor. Either situation would place their migrants at greater risk of being exploited by traffickers. On the "demand side", trafficking risk may exhibit an inverted-U shape as a function of income. Wealthier migrants can employ more reliable methods of migration, reducing their risk. Poorer migrants may face less risk because they lack the resources to pay anything but minimal fees to labor contractors. As a result, traffickers may target migrants in the middle income group, households from which traffickers can extract significant fees in the course of the failed migration.

We attempt to test for the various hypothesized forms of non-linearity in income using several different transformations besides raw income level (standardized VND per month). We first tried a pseudo log-transformation using the inverse hyperbolic sine transform ${ }^{5}$. We also created a nonparametric measure of relative income by creating a series of dummies representing income quintiles. Interestingly, neither of these measures were large or statistically significant.

In addition to the log transform and decile measures described above, we computed per person and per household incomes, both including and excluding migrant members' income (remittances not counted as part of income). Again, none of these measures were large or statistically significant in any specification. Results of these specifications are available upon request.

The distribution of $\log$ transformed adult ${ }^{6}$ monthly income for trafficking source households and nonsource households is shown in Figure 3. We can see that non-source households have a higher density to the right of the median, though not by very much, and the distribution below the median does not show any clear differences between source and non-source households. In fact, income seems to follow largely similar patterns between the two groups, as confirmed by a two-sample Kolmogorov-Smirnov test for equality of distributions, which was not significant. The insignificance of income calls into question the relevance of income as a long-hypothesized leading factor in trafficking vulnerability. If sex and income have little predictive power, the question then becomes what characteristics are associated with trafficking? Our most statistically significant and robust results come from various measures of education, on the village, household and individual levels.

Education at the household level, measured as the average years of schooling, is highly significant and negatively associated with trafficking risk across specifications. This intuitively makes sense: more educated households might be better able to discern legitimate from illegitimate migration opportunities. However, individual education is highly significant and positively associated with trafficking risk across specifications. This result holds whether individual education is defined as the raw number of years of education, or as the difference between an individual's education and their household's average. A similar result holds at the village level, with average village education being negatively associated with trafficking risk while individual education (measured as an individual's

\footnotetext{
${ }^{5}$ The inverse hyperbolic sine transform, $\ln \left(x+\sqrt{x^{2}+1}\right)$, approximates $\ln (2)+\ln (x)$, making it interpretable in the same way as a standard log transform, with the important exception that it is defined at zero. This makes it well suited to dealing with wealth and income data, which often contains a large number of zero values (Burbidge, Magee, and Robb 1988).

${ }^{6}$ We follow the convention WHO and define children as 14 and younger.
} 
deviation from the village average) remains significant and positive across specifications.

While at first this may seem like a puzzling pattern, note that a similar pattern in education holds if the outcome variable is changed from trafficking victim to migrant, as can be seen in Table 4 . This fits in neatly with the idea that migration is in many respects a household and, perhaps to some extent, village level decision. More educated households overall may feel less pressure to send a migrant, but when a migrant is sent, the household sends the individual likely to be the best earner, thereby maximizing their combined household earnings.

That being said, the pattern observed for trafficking victims is not simply a consequence of them being migrants. Even when the analysis is run on the restricted sample of only migrant households, the same pattern holds, as shown in Table 5. The mechanism driving this pattern, and why it should hold for trafficking victims even above and beyond migrants, remains unclear. It could have to do with household decisions, as outlined above, or it could be the result of targeting by traffickers. For example, perhaps, among possible migrant populations, traffickers target households with lower education levels and seek their most educated member, perhaps allowing them to both

more easily deceive the household, and fetch a higher price for themselves by trafficking a more educated individual.

There are potential sample selection issues here since, except in extreme cases, only individuals who decide to migrate are at risk of being trafficked. As can be seen in Table 4, the decision to migrate is hardly a random process. To solve this selection problem, we apply a Heckman-style bivariate probit with selection, which models trafficking vulnerability taking into account the process underlying the decision to migrate. Identification for this model requires at least one variable that is significant in the selection equation which can be omitted from the main specification. For this, we chose household and individual employment variables. Since migration in this context is almost always related to labor, employment plays a large role in most migration decisions, as lack of employment at home or the promise of better work elsewhere can increase the pressure to migrate. However, once the decision to migrate for work is made, it is unlikely that employment status plays much, if any, role in trafficking vulnerability. Results are presented in Table 6, and are largely consistent with results presented above.

\subsection{Anchoring vignettes}

\subsubsection{General features}

Quantifying a difficult to describe concept in a way that is consistent with both the researcher's understanding of the issue and the understanding of other respondents is a major problem in survey research. Human trafficking is a complex issue, the exact definition of which still varies considerably between different organizations, protocols and researchers (Laczko and Goździak 2005). In any attempt to survey people about human trafficking, then, precautions must be taken to ensure that 
the respondent understands the concept as the researcher expects them to. One technique to alleviate this problem is anchoring vignettes.

Anchoring vignettes are a way of directly measuring incomparability between responses, and then correct for it during the analysis stage. Specifically, this involves asking the respondent the question of interest, as it relates to themselves, as well as an assessment of several hypothetical persons and situations in the form of vignettes. The vignettes are designed to measure the individual's understanding of the various dimensions and nuances of the original question. This can then be used to adjust their response to be directly comparable with answers from other respondents, even if they have different understandings of the original question. Anchoring vignettes then offer a way to measure and adjust for interrespondent incomparability, sometimes referred to as the differential item functioning, or DIF (King et al. 2004).

In this particular case, in addition to asking direct questions about trafficking, we asked a series of anchoring vignettes designed to touch upon the various forms that trafficking can take, as well as some of the common misconceptions about what constitutes trafficking. Anchoring vignettes are most often used when respondents are asked for answers on some sort of ordinal scale (e.g. a 1-5 Likert scale), while here we attempt to utilize them to adjust a binary response. We asked three vignettes, which were slightly modified between subjects to have gender agreement with each respondent's particular situation.

- Suppose Mr[s]. Minh is promised a job in [China/Laos/Cambodia/Malaysia/others] by a labor contractor. Upon his/her arrival, their employers confiscate their documents and refuse to return them until he/she has worked off their travel expenses. Would you consider this human trafficking?

- Suppose Mr[s]. Minh pays an agent to bring him/her to a new job in [China/Laos/Cambodia/ Malaysia/others], even though Mr[s]. Minh doesn't have the proper travel documents. Would you consider this human trafficking?

- $\operatorname{Mr}[\mathrm{s}]$. Minh pays an agent to bring him/her to a new job in [China/Laos/Cambodia/Malaysia/ others]. His/her new employer has Mr[s]. Minh working long hours in hot, dirty conditions that make $\operatorname{Mr}[\mathrm{s}]$. Minh ill sometimes. $\operatorname{Mr}[\mathrm{s}]$. Minh must continue in the job until he can save enough money to return home. Would you conisder this human trafficking?

The first and third vignettes attempt to address the core characteristic of trafficking, namely the elements of coercion or force. The second vignette attempts to identify respondents who incorrectly believe that illegal migration, with no element of coercion, constitutes trafficking.

The results of the anchoring vignettes are presented in Table 7. As can be seen, the majority of respondents answered vignettes 1 and 3 correctly. However, only about $40 \%$ of respondents overall answered the vignette 2 , the illegal migration vignette, correctly. This low percentage is mainly due to incorrect responses from non-migrant and migrant households (38\% and $41 \%$ correct); trafficked 
households and respondents who had migrated previously did better on this vignette (56\% correct for both). This is encouraging for our results, as the group who is being most relied upon to be able to differentiate trafficking from illegal migration seems to have the best comprehension of the issue on average. Interestingly, they were slightly worse than other groups on vignettes 1 and 3 . As these vignettes were examples of trafficking, poorer performance suggests that they might underestimate trafficking events as compared to the other groups.

We also calculate Cronbach's alpha for each group. Cronbach's alpha is commonly used as a measure of test reliability, the internal consistency of items meant to be measuring the same thing (Cronbach 1951). Cronbach's alpha is widely used as a simple measure of the degree to which various questions all measure some dimension of a latent construct ${ }^{7}$. An alpha of 1 is perfect, and an alpha of 0 denotes complete noise.

\subsubsection{Restricted regression samples}

As a robustness check, we chose the traditional logit model with the lowest Akaike Information Criteria (AIC), a measure of relative model quality (Akaike 1974), and run it restricted to respondents who answered at least vignette 1 correctly, vignette 2 correctly or vignette 3 correctly, as well as respondents who answered 1, 2 or 3 vignettes correctly. The model was unable to converge properly when restricted only to households that answered 3 vignettes correctly, but otherwise the results are largely consistent with those presented above, as shown in Table 6. These sensitivities were run on all our other models as well, the results of which are presented in the appendix.

Respondents were also asked why they believed their household member had been trafficked. Results are presented in Table 9. Every respondent cited lack of contact as one reason, followed by $36.8 \%$ reporting that the victim themselves told them. No respondents reported receiving information from law enforcement or government officials.

\subsubsection{Factor analysis}

Another way of testing for how understanding affects response to trafficking questions is to include a measure of respondent understanding directly in the regression equation. Our anchoring vignettes are theoretically meant to provide measurements of a latent "trafficking understanding" variable. As such, correct responses are correlated across vignettes. To account for this correlation and obtain a more direct, if less easily interpretable, measure of this latent variable, we perform factor analysis on the vignette responses. We can then include an individual's factor score(s) directly in our regression specification, without the multicollinearity issues that could arise from including the raw vignette responses in the equation. A worst case scenario would be to find a significant and

\footnotetext{
${ }^{7}$ Alpha is calculated as $\alpha=\frac{K}{K-1}\left(1-\frac{\sum_{i=1}^{K} \sigma_{Y_{i}}^{2}}{\sigma_{X}^{2}}\right)$ where $K$ is the number of questions, $\sigma_{X}^{2}$ is the variance of all responses, and $\sigma_{Y_{i}}^{2}$ is the variance of each individual response.
} 
negative coefficient on the factor score, as this would imply that the less an individual understands the concept of trafficking, the more (conditionally) likely they are to report a household member as trafficked.

Table 10 presents the results of a series of household level regressions (the vignettes were asked only to the primary respondent in each household) including the first principal component (which accounts for $70.3 \%$ of the observed variation in the three vignettes) as an explanatory variable. In no specification is the coefficient on the first component significant, and the coefficient is positive once village level fixed effects are accounted for using conditional logistic regressions. Essentially, the lack of a significant megative relationship here implies that people are not simply reporting family members trafficked based on a misunderstanding of the concept of trafficking.

\section{$5 \quad$ Policy implications}

These results carry a number of important implications for those crafting trafficking policy. The results of this pilot project are consistent with the ILO finding that most victims of human trafficking are engaged in forced labor rather than sex trafficking. The sex of the migrant was a poor predictor of both migration and trafficking. A greater focus is needed on labor market policies that can reduce the vulnerability of migrants and other workers to trafficking. The prevalence of human trafficking from failed labor migration calls for a more balanced approach targeting a wider range of trafficked persons.

The results on income levels suggest that human trafficking is not purely a problem of circumstance. The fact that income cannot predict trafficking vulnerability tells us that trafficking is not a problem that will simply disappear as development progresses and incomes rise.

Our results suggest that increasing education levels may be effective in reducing households' vulnerability to trafficking. As with many development issues, better education across all household members appears to improve migration outcomes.

Human trafficking is not just a crime against the victim, it also adversely affects the source household. Besides the emotional trauma, there are additional economic consequences to a household losing one of it's most productive members. For example, remittances can be a significant part of the household's budget. Table 11 shows what actions households report they would have to take as

a consequence of losing these remittances. Fifty-six percent of households report that they would increase their use of credit and loans, which is unsustainable in the long term. Otherwise, households would reduce non-durable and service expenditures, work more hours and take on a new job in almost equal numbers. Such losses to the source households should be a factor in determining the allocation of resources among various anti-trafficking activities.

Despite the results on education, it does not appear that lack of information on the risks of trafficking is a key factor in vulnerability: people generally seem to know that trafficking is a risk in migration. 
The question then becomes whether this is a risk that enters realistically into households' utility maximization calculation, or if this stems primarily from behavioral fallacies and poorly estimated risks. We hope to address this question, among others, in future research.

\section{Conclusion}

Human trafficking is one of the largest issues facing international law enforcement and migration policy makers today, yet reliable micro-level data on human trafficking remains scarce. We present here a possible framework for collecting such data that is straightforward to implement and applicable to a wide variety of developing countries. Despite being a small-scale pilot study, a number of surprising features arise in our analysis, further emphasizing the historical lack of empirical rigor applied to the study of human trafficking and the importance of high quality data in effectively fighting trafficking. 


\section{References}

Akaike, Hirotugu. 1974. "A new look at statistical model identification." IEEE Transactions on Automatic Control 19 (6): 716-723.

Burbidge, John B., Lonnie Magee, and A. Leslie Robb. 1988. "Alternative transformations to handle extreme values of the dependent variable." Journal of the American Statistical Association 83 (401): 123-127.

Cameron, Colin A., Jonah B. Gelbach, and Douglas L. Miller. 2011. "Robust inference with multiway clustering." Journal of Business and Economic Statistics 2:238-249.

Chamberlain, Gary. 1980. "Analysis of Covariance with Qualitative Data." Review of Economic Studies 47 (1): 225-238.

Cronbach, J. Lee. 1951. "Coefficient alpha and the internal structure of tests." Psychometrika 16:297-334.

Dumont, Jean-Christophe, and Bela Hovy. 2013. "World Migration in Figures 2013." Technical Report, OECD-UNDESA.

Goździak, Elżbieta M., and Micah N. Bump. 2008. "Data and research on human trafficking: Bibliography of research-based literature." Technical Report, Institute for the Study of International Migration, Walsh School of Foreign Service, Georgetown University.

International Labor Organization. 2007a. "Decent work indicators: towards better statistics on forced labour and human trafficking."

—. 2007b. "The Mekong challenge: winding roads: young migrants from Lao PDR and their vulnerability to human trafficking."

—. 2012. "ILO global estimate of forced labor."

King, Gary, Christopher JL Murray, Joshua A. Salomon, and Ajay Tandon. 2004. "Enhancing the validity and cross-cultural comparability of measurement in survey research." American Political Science Review 98 (1): 191-207.

King, Gary, and Langche Zeng. 2001a. "Explaining rare events in international relations." International Organization 55 (3): 693-715.

—. 2001b. "Logistic regression in rare events data." Political analysis 9 (2): 137-163.

Laczko, Frank, and Elżbieta M. Goździak. 2005. Data and research on human trafficking: A global survey. Volume 43. United Nations Publications.

MacKinnon, James G., and Halbert White. 1985. "Some heteroskedasticity-consistent covariance matrix estimators with improved finite sample properties." Journal of Econometrics 29 (3): 305-325.

Omar Mahmoud, Toman, and Christoph Trebesch. 2009. "The Economic Drivers of Human Trafficking: Micro-Evidence from Five Eastern European Countries." 
- 2010. "The economics of human trafficking and labour migration: Micro-evidence from Eastern Europe." Journal of Comparative Economics 38 (2): 173-188.

Pepper, John V. 2002. "Robust inferences from random clustered samples: an application using data from the Panel Study of Income Dynamics." Economics Letters 75:341-345.

Ratha, Dilip, Sanket Mohapatra, and Ani Silwal. 2010. Migration and Remittances Factbook 2011. 2. World Bank.

Rennison, Callie Marie, and Michael Rand. 2007. Chapter Introduction to the National Crime Victimization Survey of Understanding crime statistics: revisiting the divergence of the NCVS and UCR, edited by James Patrick Lynch, Lynn A. Addington, A. Blumstein, and David P. Farrington, 17-54. Cambridge University Press.

Shamir, Hila. 2012. "A labor paradigm for human trafficking." UCLA Law Review 60 (1): 76-136.

UNESCO Bangkok. Trafficking statistics project.

UNIAP. 2011. "A quantitative analysis on human trafficking: the case of An Giang Province."

United Nations. 2003. Protocol to prevent, suppress and punish trafficking in persons, especially women and children. United Nations. 
Figure 1: Maps of study location

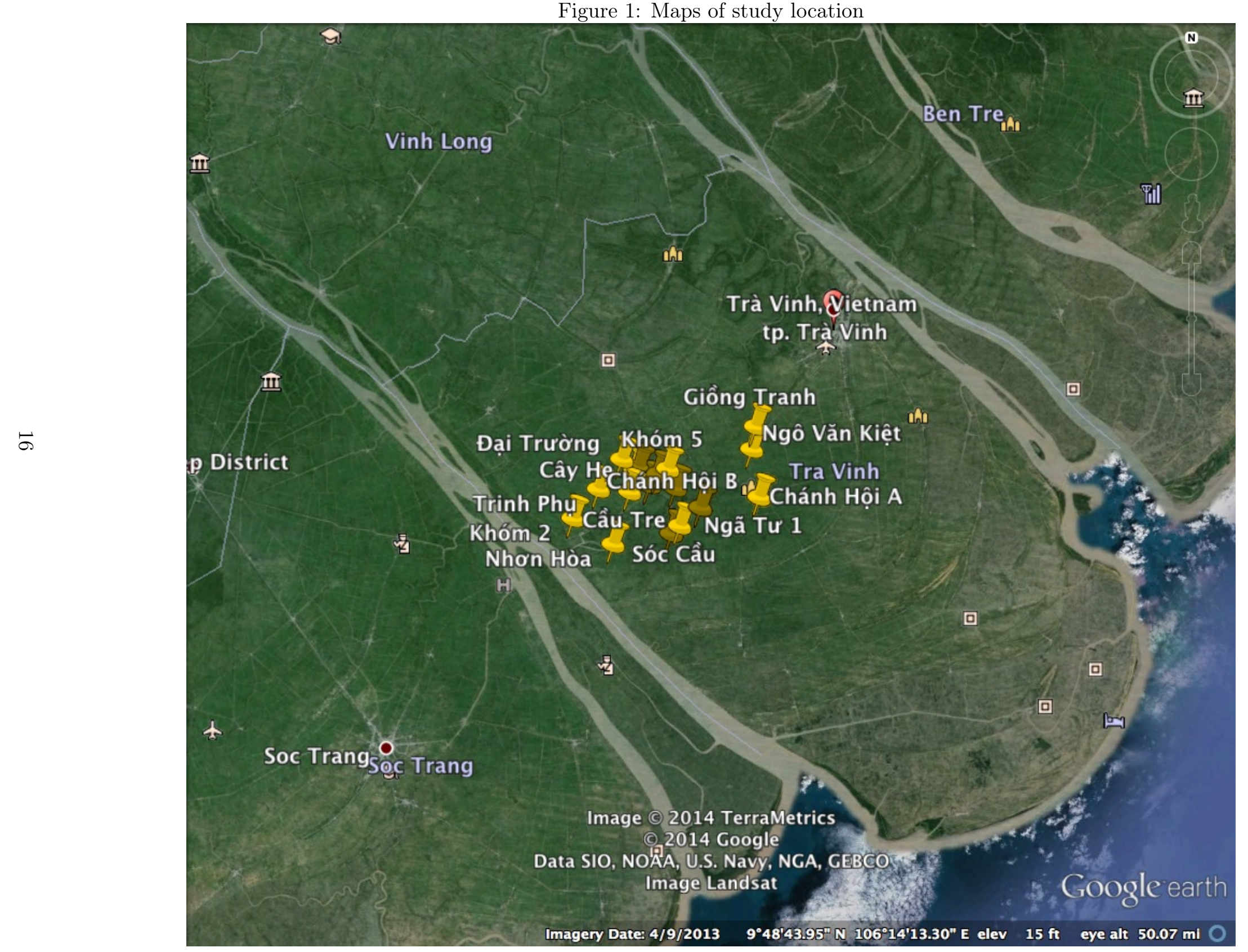


Figure 2: Age: migrants vs. non-migrants

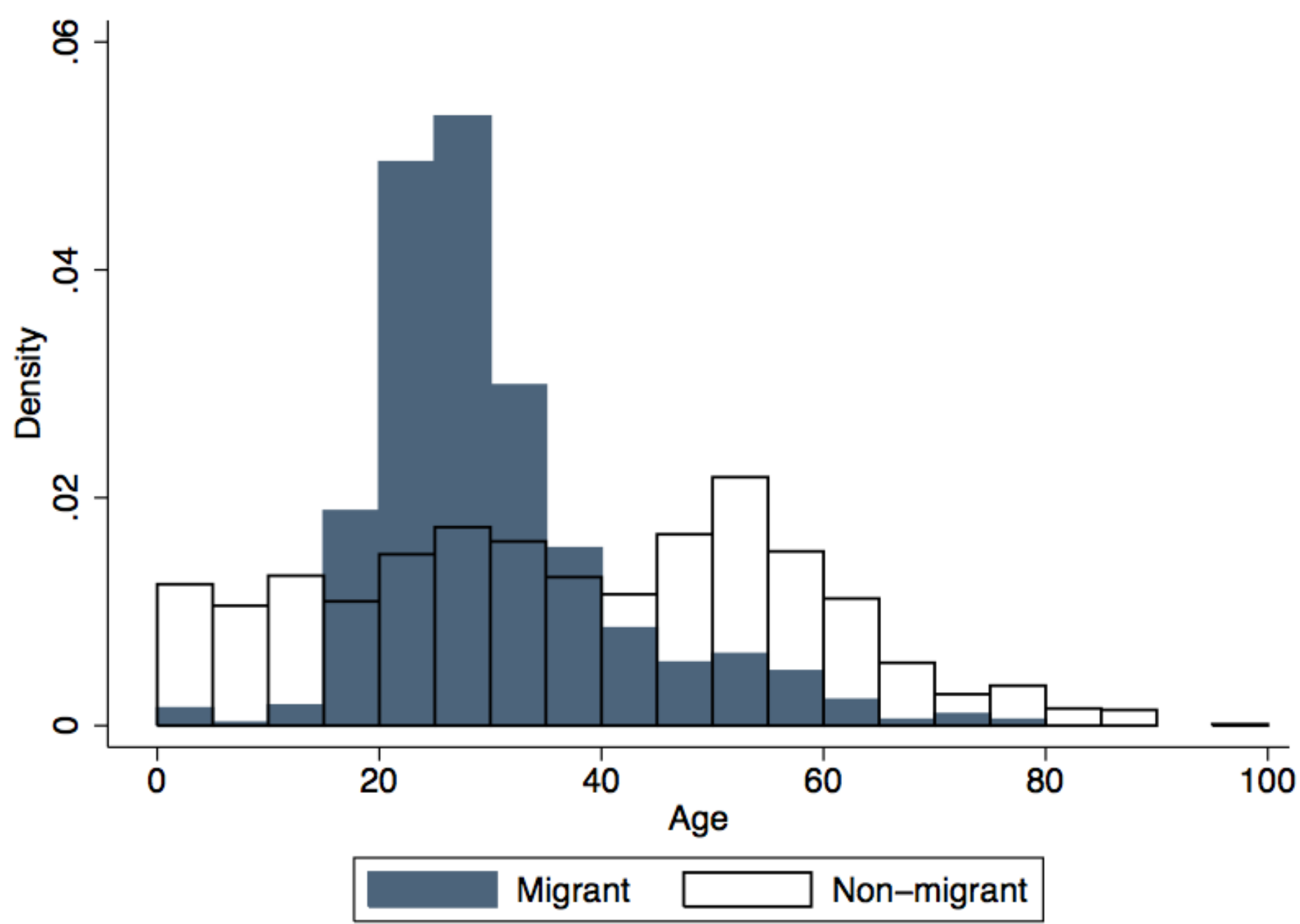


Figure 3: Log income: trafficking source vs. non-source households

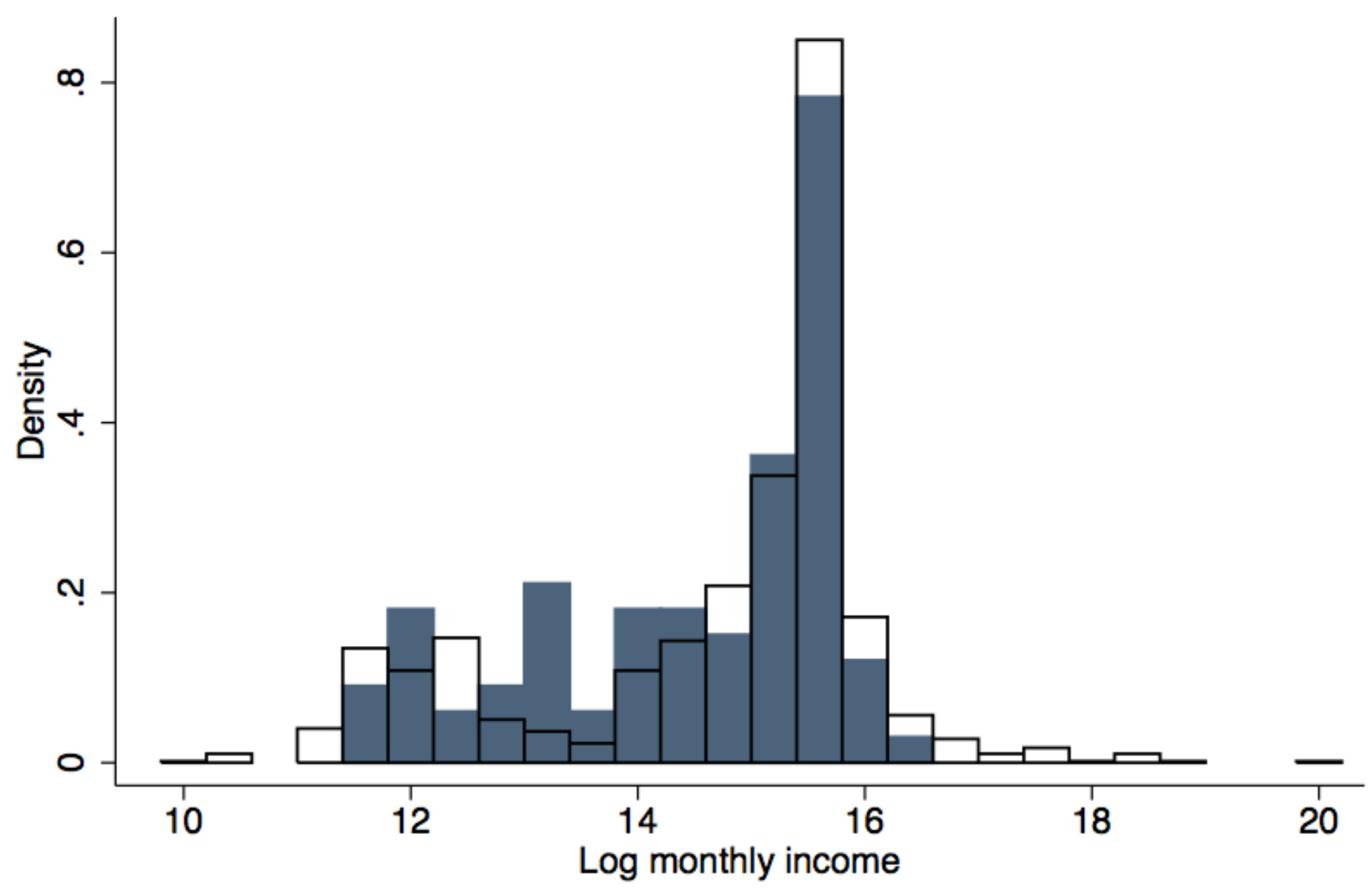

Source household Non-source household 
Table 1: Descriptive statistics: individual-level

\begin{tabular}{lcccc}
\hline & All & Non-migrants & Migrants & Trafficked \\
\hline Age & 33.11 & 36.46 & 29.53 & 28.58 \\
& $(18.08)$ & $(20.34)$ & $(11.04)$ & $(10.27)$ \\
Gender (1=male) & 0.47 & 0.46 & 0.49 & 0.53 \\
Education completed (years) & $(0.50)$ & $(0.50)$ & $(0.50)$ & $(0.51)$ \\
& 3.06 & 2.76 & 3.69 & 3.42 \\
Married & $(1.49)$ & $(1.43)$ & $(1.56)$ & $(1.31)$ \\
& 0.55 & 0.58 & 0.48 & 0.50 \\
Attending school & $(0.50)$ & $(0.49)$ & $(0.50)$ & $(0.51)$ \\
& 0.14 & 0.17 & 0.05 & 0.08 \\
Employed & $(0.35)$ & $(0.37)$ & $(0.22)$ & $(0.27)$ \\
& 0.67 & 0.57 & 0.92 & 0.89 \\
Income (10,000 VND per month) & $(0.47)$ & $(0.50)$ & $(0.27)$ & $(0.31)$ \\
& 233.32 & 183.14 & 340.89 & 241.75 \\
Sends remittances & $(531.95)$ & $(302.17)$ & $(906.54)$ & $(126.20)$ \\
Migrated abroad & 0.14 & 0.00 & 0.71 & 0.63 \\
& $(0.35)$ & $(0.00)$ & $(0.45)$ & $(0.49)$ \\
& 0.02 & 0.00 & 0.08 & 0.03 \\
& $(0.12)$ & $(0.00)$ & $(0.27)$ & $(0.16)$ \\
\hline
\end{tabular}

Notes: Individual-level descriptive statistics of sample. For each item we report the mean and standard deviation in parentheses. Column 1 uses survey weights to correct for the oversampling of migrant households. $10,000 \mathrm{VND}$ is equal to roughly $0.50 \mathrm{USD}$. 
Table 2: Descriptive statistics: household-level

\begin{tabular}{lcccc}
\hline & All & Non-migrants & Migrants & Trafficked \\
\hline Household size & 4.65 & 4.40 & 4.92 & 4.78 \\
& $(1.57)$ & $(1.50)$ & $(1.61)$ & $(1.55)$ \\
Total children in household & 0.72 & 0.87 & 0.55 & 0.44 \\
& $(0.86)$ & $(0.90)$ & $(0.78)$ & $(0.75)$ \\
Average household education & 3.05 & 3.03 & 3.07 & 2.63 \\
Total household members employed & $(0.90)$ & $(0.76)$ & $(1.04)$ & $(0.81)$ \\
& 3.12 & 2.88 & 3.39 & 3.26 \\
Household income (10,000 VND per month) & $(1.51)$ & $(1.49)$ & $(1.49)$ & $(1.65)$ \\
& 672.97 & 524.49 & 837.55 & 518.33 \\
Number of members sending remittances & $(1062.46)$ & $(555.39)$ & $(1410.84)$ & $(352.21)$ \\
& 0.66 & 0.00 & 1.39 & 1.07 \\
Number of victims known & $(1.01)$ & $(0.00)$ & $(1.08)$ & $(1.00)$ \\
& 0.47 & 0.41 & 0.54 & 1.15 \\
Number of victims returned & $(1.62)$ & $(1.04)$ & $(2.08)$ & $(1.35)$ \\
& 0.29 & 0.26 & 0.33 & 0.67 \\
& $(1.30)$ & $(0.71)$ & $(1.73)$ & $(1.04)$ \\
\hline
\end{tabular}

Notes: Individual-level descriptive statistics of sample. For each item we report the mean and standard deviation in parentheses. Column 1 uses survey weights to correct for the oversampling of migrant households. $10,000 \mathrm{VND}$ is equal to roughly $0.50 \mathrm{USD}$. 
Table 3: Predictors of trafficking vulnerability

\begin{tabular}{|c|c|c|c|c|c|c|c|c|c|}
\hline & \multicolumn{3}{|c|}{ Logit } & \multicolumn{3}{|c|}{ RE-Adjusted Logit } & \multicolumn{3}{|c|}{ Conditional Logit } \\
\hline & (1) & $(2)$ & $(3)$ & $(4)$ & (5) & $(6)$ & (7) & (8) & $(9)$ \\
\hline Within-household education difference & $\begin{array}{c}0.592^{* * *} \\
(0.142)\end{array}$ & $\begin{array}{c}0.563^{* * *} \\
(0.125)\end{array}$ & $\begin{array}{c}0.523^{* * *} \\
(0.155)\end{array}$ & $\begin{array}{c}0.592^{* * *} \\
(0.142)\end{array}$ & $\begin{array}{c}0.560^{* * *} \\
(0.125)\end{array}$ & $\begin{array}{c}0.525^{* * *} \\
(0.154)\end{array}$ & $\begin{array}{c}0.510^{* * *} \\
(0.117)\end{array}$ & $\begin{array}{c}0.521^{* * *} \\
(0.115)\end{array}$ & $\begin{array}{c}0.469^{* * *} \\
(0.135)\end{array}$ \\
\hline Average household education & $\begin{array}{l}-0.647 \\
(0.430)\end{array}$ & $\begin{array}{c}-0.810^{* *} \\
(0.373)\end{array}$ & $\begin{array}{c}-0.756^{*} \\
(0.438)\end{array}$ & $\begin{array}{l}-0.618 \\
(0.428)\end{array}$ & $\begin{array}{c}-0.783^{* *} \\
(0.372)\end{array}$ & $\begin{array}{l}-0.730^{*} \\
(0.436)\end{array}$ & $\begin{array}{l}-0.552 \\
(0.375)\end{array}$ & $\begin{array}{c}-0.749^{* *} \\
(0.302)\end{array}$ & $\begin{array}{l}-0.714^{*} \\
(0.377)\end{array}$ \\
\hline Household income per person & $\begin{array}{l}-0.000 \\
(0.000)\end{array}$ & & $\begin{array}{l}-0.000 \\
(0.000)\end{array}$ & $\begin{array}{c}-0.000 \\
(0.000)\end{array}$ & & $\begin{array}{l}-0.000 \\
(0.000)\end{array}$ & $\begin{array}{c}-0.000^{*} \\
(0.000)\end{array}$ & & $\begin{array}{c}-0.000^{* *} \\
(0.000)\end{array}$ \\
\hline Percentage of household employed & $\begin{array}{c}1.815 \\
(1.241)\end{array}$ & & $\begin{array}{c}0.795 \\
(1.464)\end{array}$ & $\begin{array}{c}1.718 \\
(1.237)\end{array}$ & & $\begin{array}{c}0.686 \\
(1.457)\end{array}$ & $\begin{array}{c}2.022 \\
(1.461)\end{array}$ & & $\begin{array}{c}0.788 \\
(1.564)\end{array}$ \\
\hline Employed & $\begin{array}{c}0.872^{*} \\
(0.514)\end{array}$ & & $\begin{array}{l}0.890^{*} \\
(0.528)\end{array}$ & $\begin{array}{c}0.762 \\
(0.513)\end{array}$ & & $\begin{array}{c}0.743 \\
(0.525)\end{array}$ & $\begin{array}{l}1.068^{* *} \\
(0.458)\end{array}$ & & $\begin{array}{l}0.999^{* *} \\
(0.454)\end{array}$ \\
\hline Married & $\begin{array}{c}-0.202 \\
(0.246)\end{array}$ & $\begin{array}{c}0.318 \\
(0.296)\end{array}$ & $\begin{array}{c}0.205 \\
(0.305)\end{array}$ & $\begin{array}{l}-0.196 \\
(0.245)\end{array}$ & $\begin{array}{c}0.300 \\
(0.295)\end{array}$ & $\begin{array}{c}0.188 \\
(0.304)\end{array}$ & $\begin{array}{c}-0.440^{* *} \\
(0.191)\end{array}$ & $\begin{array}{c}0.044 \\
(0.232)\end{array}$ & $\begin{array}{c}-0.107 \\
(0.203)\end{array}$ \\
\hline Gender $(1=$ male $)$ & $\begin{array}{c}0.067 \\
(0.318)\end{array}$ & $\begin{array}{c}0.058 \\
(0.319)\end{array}$ & $\begin{array}{c}0.042 \\
(0.337)\end{array}$ & $\begin{array}{c}0.066 \\
(0.317)\end{array}$ & $\begin{array}{c}0.052 \\
(0.318)\end{array}$ & $\begin{array}{c}0.037 \\
(0.335)\end{array}$ & $\begin{array}{c}0.032 \\
(0.327)\end{array}$ & $\begin{array}{c}0.056 \\
(0.340)\end{array}$ & $\begin{array}{c}0.002 \\
(0.349)\end{array}$ \\
\hline Household size & & $\begin{array}{l}-0.010 \\
(0.119)\end{array}$ & $\begin{array}{l}-0.036 \\
(0.113)\end{array}$ & & $\begin{array}{l}-0.004 \\
(0.119)\end{array}$ & $\begin{array}{l}-0.027 \\
(0.112)\end{array}$ & & $\begin{array}{c}0.195 \\
(0.137)\end{array}$ & $\begin{array}{c}0.176 \\
(0.123)\end{array}$ \\
\hline Total children in household & & $\begin{array}{c}-0.856^{* * *} \\
(0.168)\end{array}$ & $\begin{array}{c}-0.691^{* * *} \\
(0.258)\end{array}$ & & $\begin{array}{c}-0.807^{* * *} \\
(0.167)\end{array}$ & $\begin{array}{c}-0.662^{* * *} \\
(0.257)\end{array}$ & & $\begin{array}{c}-1.066^{* * *} \\
(0.181)\end{array}$ & $\begin{array}{c}-0.948^{* * *} \\
(0.235)\end{array}$ \\
\hline Age & & $\begin{array}{c}-0.025^{* * *} \\
(0.009)\end{array}$ & $\begin{array}{c}-0.027^{* *} \\
(0.011)\end{array}$ & & $\begin{array}{c}-0.023^{* *} \\
(0.009)\end{array}$ & $\begin{array}{c}-0.024^{* *} \\
(0.011)\end{array}$ & & $\begin{array}{c}-0.016^{* *} \\
(0.008)\end{array}$ & $\begin{array}{c}-0.017^{*} \\
(0.009)\end{array}$ \\
\hline Constant & $\begin{array}{c}-4.175^{* * *} \\
(1.225)\end{array}$ & $\begin{array}{l}-0.917 \\
(0.638)\end{array}$ & $\begin{array}{l}-1.939^{*} \\
(1.133)\end{array}$ & $\begin{array}{c}-4.035^{* * *} \\
(1.220)\end{array}$ & $\begin{array}{c}-0.972 \\
(0.636)\end{array}$ & $\begin{array}{l}-1.838 \\
(1.128)\end{array}$ & & & \\
\hline Observations & 2394 & 2394 & 2394 & 2394 & 2394 & 2394 & 1828 & 1828 & 1828 \\
\hline
\end{tabular}

Notes: Logistic regression results for human trafficking vulnerability and their standard errors in parentheses. Columns 1-3 are traditional logistic estimates, Columns 4-6 apply the rare events correction and Columns 7-9 are from a conditional logistic model with village-level fixed effects. Standard errors are heteroskedasticity robust and clustered by village. ${ }^{*}$ denotes significance at the $10 \%$ level, ${ }^{* *}$ at the $5 \%$ level and $* * *$ at the $1 \%$ level. 
Table 4: Predictors of migration

\begin{tabular}{|c|c|c|c|c|c|c|c|c|c|}
\hline & \multicolumn{3}{|c|}{ Logit } & \multicolumn{3}{|c|}{ RE-Adjusted Logit } & \multicolumn{3}{|c|}{ Conditional Logit } \\
\hline & $(1)$ & $(2)$ & (3) & $(4)$ & $(5)$ & $(6)$ & $(7)$ & $(8)$ & $(9)$ \\
\hline Within-household education difference & $\begin{array}{c}0.506^{* * *} \\
(0.066)\end{array}$ & $\begin{array}{c}0.624^{* * *} \\
(0.054)\end{array}$ & $\begin{array}{c}0.384^{* * *} \\
(0.056)\end{array}$ & $\begin{array}{c}0.504^{* * *} \\
(0.066)\end{array}$ & $\begin{array}{c}0.621^{* * *} \\
(0.054)\end{array}$ & $\begin{array}{c}0.381^{* * *} \\
(0.056)\end{array}$ & $\begin{array}{c}0.510^{* * *} \\
(0.067)\end{array}$ & $\begin{array}{c}0.636^{* * *} \\
(0.056)\end{array}$ & $\begin{array}{c}0.395^{* * *} \\
(0.059)\end{array}$ \\
\hline Average household education & $\begin{array}{c}0.080 \\
(0.121)\end{array}$ & $\begin{array}{l}-0.088 \\
(0.131)\end{array}$ & $\begin{array}{l}-0.029 \\
(0.126)\end{array}$ & $\begin{array}{c}0.080 \\
(0.120)\end{array}$ & $\begin{array}{l}-0.087 \\
(0.131)\end{array}$ & $\begin{array}{l}-0.029 \\
(0.126)\end{array}$ & $\begin{array}{c}0.096 \\
(0.145)\end{array}$ & $\begin{array}{l}-0.073 \\
(0.152)\end{array}$ & $\begin{array}{l}-0.012 \\
(0.145)\end{array}$ \\
\hline Household income per person & $\begin{array}{c}0.000 \\
(0.000)\end{array}$ & & $\begin{array}{c}0.000 \\
(0.000)\end{array}$ & $\begin{array}{c}0.000 \\
(0.000)\end{array}$ & & $\begin{array}{c}0.000 \\
(0.000)\end{array}$ & $\begin{array}{c}0.000 \\
(0.000)\end{array}$ & & $\begin{array}{c}0.000 \\
(0.000)\end{array}$ \\
\hline Percentage of household employed & $\begin{array}{c}-0.940^{* *} \\
(0.416)\end{array}$ & & $\begin{array}{c}-1.893^{* * *} \\
(0.468)\end{array}$ & $\begin{array}{c}-0.935^{* *} \\
(0.415)\end{array}$ & & $\begin{array}{c}-1.879^{* * *} \\
(0.465)\end{array}$ & $\begin{array}{c}-0.721^{*} \\
(0.433)\end{array}$ & & $\begin{array}{c}-1.731^{* * *} \\
(0.466)\end{array}$ \\
\hline Employed & $\begin{array}{c}2.548^{* * *} \\
(0.195)\end{array}$ & & $\begin{array}{c}2.785^{* * *} \\
(0.256)\end{array}$ & $\begin{array}{c}2.533^{* * *} \\
(0.195)\end{array}$ & & $\begin{array}{c}2.762^{* * *} \\
(0.255)\end{array}$ & $\begin{array}{c}2.643^{* * *} \\
(0.206)\end{array}$ & & $\begin{array}{c}2.862^{* * *} \\
(0.265)\end{array}$ \\
\hline Married & $\begin{array}{c}-0.951^{* * *} \\
(0.108)\end{array}$ & $\begin{array}{l}-0.100 \\
(0.141)\end{array}$ & $\begin{array}{c}-0.581^{* * *} \\
(0.150)\end{array}$ & $\begin{array}{c}-0.947^{* * *} \\
(0.108)\end{array}$ & $\begin{array}{l}-0.101 \\
(0.140)\end{array}$ & $\begin{array}{c}-0.579^{* * *} \\
(0.149)\end{array}$ & $\begin{array}{c}-0.987^{* * *} \\
(0.107)\end{array}$ & $\begin{array}{l}-0.081 \\
(0.142)\end{array}$ & $\begin{array}{c}-0.616^{* * *} \\
(0.154)\end{array}$ \\
\hline Gender $(1=$ male $)$ & $\begin{array}{c}-0.084 \\
(0.126)\end{array}$ & $\begin{array}{l}-0.019 \\
(0.139)\end{array}$ & $\begin{array}{c}-0.077 \\
(0.132)\end{array}$ & $\begin{array}{c}-0.083 \\
(0.126)\end{array}$ & $\begin{array}{l}-0.019 \\
(0.139)\end{array}$ & $\begin{array}{c}-0.077 \\
(0.131)\end{array}$ & $\begin{array}{c}-0.079 \\
(0.133)\end{array}$ & $\begin{array}{l}-0.008 \\
(0.146)\end{array}$ & $\begin{array}{l}-0.070 \\
(0.139)\end{array}$ \\
\hline Household size & & $\begin{array}{c}0.173^{* * *} \\
(0.042)\end{array}$ & $\begin{array}{c}0.176^{* * *} \\
(0.047)\end{array}$ & & $\begin{array}{c}0.173^{* * *} \\
(0.041)\end{array}$ & $\begin{array}{c}0.175^{* * *} \\
(0.046)\end{array}$ & & $\begin{array}{c}0.184^{* * *} \\
(0.040)\end{array}$ & $\begin{array}{c}0.180^{* * *} \\
(0.044)\end{array}$ \\
\hline Total children in household & & $\begin{array}{c}-0.590^{* * *} \\
(0.094)\end{array}$ & $\begin{array}{c}-0.579^{* * *} \\
(0.115)\end{array}$ & & $\begin{array}{c}-0.587^{* * *} \\
(0.094)\end{array}$ & $\begin{array}{c}-0.576^{* * *} \\
(0.114)\end{array}$ & & $\begin{array}{c}-0.612^{* * *} \\
(0.099)\end{array}$ & $\begin{array}{c}-0.573^{* * *} \\
(0.114)\end{array}$ \\
\hline Age & & $\begin{array}{c}-0.019^{* * *} \\
(0.004)\end{array}$ & $\begin{array}{c}-0.033^{* * *} \\
(0.007)\end{array}$ & & $\begin{array}{c}-0.019^{* * *} \\
(0.004)\end{array}$ & $\begin{array}{c}-0.032^{* * *} \\
(0.006)\end{array}$ & & $\begin{array}{c}-0.019^{* * *} \\
(0.004)\end{array}$ & $\begin{array}{c}-0.032^{* * *} \\
(0.006)\end{array}$ \\
\hline Constant & $\begin{array}{c}-1.823^{* * *} \\
(0.310) \\
\end{array}$ & $\begin{array}{l}-0.385 \\
(0.432) \\
\end{array}$ & $\begin{array}{c}-0.697^{*} \\
(0.402) \\
\end{array}$ & $\begin{array}{c}-1.813^{* * *} \\
(0.309) \\
\end{array}$ & $\begin{array}{l}-0.385 \\
(0.431) \\
\end{array}$ & $\begin{array}{c}-0.692^{*} \\
(0.400) \\
\end{array}$ & & & \\
\hline Observations & 2394 & 2394 & 2394 & 2394 & 2394 & 2394 & 2394 & 2394 & 2394 \\
\hline
\end{tabular}

Notes: Logistic regression results for human trafficking vulnerability and their standard errors in parentheses. Columns 1-3 are traditional logistic estimates, Columns 4-6 apply the rare events correction and Columns 7-9 are from a conditional logistic model with village-level fixed effects. Standard errors are heteroskedasticity robust and clustered by village. ${ }^{*}$ denotes significance at the $10 \%$ level, ${ }^{* *}$ at the $5 \%$ level and *** at the $1 \%$ level. 
Table 5: Predictors of trafficking vulnerability: migrants only

\begin{tabular}{|c|c|c|c|c|c|c|c|c|c|}
\hline & \multicolumn{3}{|c|}{ Logit } & \multicolumn{3}{|c|}{ RE-Adjusted Logit } & \multicolumn{3}{|c|}{ Conditional Logit } \\
\hline & $(1)$ & $(2)$ & $(3)$ & (4) & $(5)$ & (6) & $(7)$ & $(8)$ & $(9)$ \\
\hline Within-household education difference & $\begin{array}{c}0.362^{* *} \\
(0.152)\end{array}$ & $\begin{array}{c}0.255^{* *} \\
(0.123)\end{array}$ & $\begin{array}{l}0.315^{* *} \\
(0.149)\end{array}$ & $\begin{array}{c}0.360^{* *} \\
(0.151)\end{array}$ & $\begin{array}{l}0.255^{\text {** }} \\
(0.122)\end{array}$ & $\begin{array}{c}0.311^{* *} \\
(0.147)\end{array}$ & $\begin{array}{l}0.160^{*} \\
(0.093)\end{array}$ & $\begin{array}{l}0.197^{*} \\
(0.118)\end{array}$ & $\begin{array}{c}0.244^{* *} \\
(0.122)\end{array}$ \\
\hline Average household education & $\begin{array}{l}-0.605 \\
(0.374)\end{array}$ & $\begin{array}{c}-0.600^{* *} \\
(0.287)\end{array}$ & $\begin{array}{c}-0.643^{*} \\
(0.373)\end{array}$ & $\begin{array}{l}-0.568 \\
(0.371)\end{array}$ & $\begin{array}{c}-0.569^{* *} \\
(0.284)\end{array}$ & $\begin{array}{c}-0.610^{*} \\
(0.367)\end{array}$ & $\begin{array}{c}-0.558^{* *} \\
(0.284)\end{array}$ & $\begin{array}{c}-0.637^{* * *} \\
(0.229)\end{array}$ & $\begin{array}{c}-0.698^{* *} \\
(0.290)\end{array}$ \\
\hline Household income per person & $\begin{array}{l}-0.000 \\
(0.000)\end{array}$ & & $\begin{array}{l}-0.000 \\
(0.000)\end{array}$ & $\begin{array}{l}-0.000 \\
(0.000)\end{array}$ & & $\begin{array}{l}-0.000 \\
(0.000)\end{array}$ & $\begin{array}{c}-0.000^{* *} \\
(0.000)\end{array}$ & & $\begin{array}{c}-0.000^{* * *} \\
(0.000)\end{array}$ \\
\hline Percentage of household employed & $\begin{array}{l}2.109^{*} \\
(1.218)\end{array}$ & & $\begin{array}{c}1.582 \\
(1.478)\end{array}$ & $\begin{array}{c}1.980 \\
(1.206)\end{array}$ & & $\begin{array}{c}1.447 \\
(1.458)\end{array}$ & $\begin{array}{l}2.465^{*} \\
(1.497)\end{array}$ & & $\begin{array}{c}1.950 \\
(1.626)\end{array}$ \\
\hline Employed & $\begin{array}{c}-1.002^{*} \\
(0.518)\end{array}$ & & $\begin{array}{c}-1.068^{* *} \\
(0.535)\end{array}$ & $\begin{array}{c}-1.095^{* *} \\
(0.513)\end{array}$ & & $\begin{array}{c}-1.184^{* *} \\
(0.528)\end{array}$ & $\begin{array}{l}-1.023^{*} \\
(0.605)\end{array}$ & & $\begin{array}{l}-1.022 \\
(0.649)\end{array}$ \\
\hline Married & $\begin{array}{c}0.190 \\
(0.287)\end{array}$ & $\begin{array}{c}0.304 \\
(0.300)\end{array}$ & $\begin{array}{c}0.373 \\
(0.327)\end{array}$ & $\begin{array}{c}0.196 \\
(0.284)\end{array}$ & $\begin{array}{c}0.291 \\
(0.297)\end{array}$ & $\begin{array}{c}0.354 \\
(0.322)\end{array}$ & $\begin{array}{c}0.105 \\
(0.281)\end{array}$ & $\begin{array}{l}-0.018 \\
(0.267)\end{array}$ & $\begin{array}{c}0.141 \\
(0.273)\end{array}$ \\
\hline Gender $(1=$ male $)$ & $\begin{array}{c}0.173 \\
(0.326)\end{array}$ & $\begin{array}{c}0.107 \\
(0.316)\end{array}$ & $\begin{array}{c}0.143 \\
(0.345)\end{array}$ & $\begin{array}{c}0.164 \\
(0.322)\end{array}$ & $\begin{array}{c}0.099 \\
(0.313)\end{array}$ & $\begin{array}{c}0.133 \\
(0.340)\end{array}$ & $\begin{array}{c}0.003 \\
(0.360)\end{array}$ & $\begin{array}{c}0.027 \\
(0.321)\end{array}$ & $\begin{array}{l}-0.032 \\
(0.364)\end{array}$ \\
\hline Household size & & $\begin{array}{l}-0.120 \\
(0.107)\end{array}$ & $\begin{array}{l}-0.147 \\
(0.109)\end{array}$ & & $\begin{array}{l}-0.112 \\
(0.106)\end{array}$ & $\begin{array}{l}-0.134 \\
(0.107)\end{array}$ & & $\begin{array}{c}0.033 \\
(0.110)\end{array}$ & $\begin{array}{c}0.030 \\
(0.114)\end{array}$ \\
\hline Total children in household & & $\begin{array}{c}-0.447^{* *} \\
(0.212)\end{array}$ & $\begin{array}{l}-0.344 \\
(0.289)\end{array}$ & & $\begin{array}{l}-0.404^{*} \\
(0.210)\end{array}$ & $\begin{array}{l}-0.311 \\
(0.285)\end{array}$ & & $\begin{array}{c}-0.613^{* * *} \\
(0.238)\end{array}$ & $\begin{array}{c}-0.597^{*} \\
(0.323)\end{array}$ \\
\hline Age & & $\begin{array}{l}-0.013 \\
(0.015)\end{array}$ & $\begin{array}{l}-0.009 \\
(0.014)\end{array}$ & & $\begin{array}{l}-0.010 \\
(0.015)\end{array}$ & $\begin{array}{l}-0.005 \\
(0.014)\end{array}$ & & $\begin{array}{c}0.004 \\
(0.015)\end{array}$ & $\begin{array}{c}0.011 \\
(0.015)\end{array}$ \\
\hline Constant & $\begin{array}{l}-1.979 \\
(1.402)\end{array}$ & $\begin{array}{l}-0.415 \\
(0.819)\end{array}$ & $\begin{array}{l}-0.279 \\
(1.415)\end{array}$ & $\begin{array}{l}-1.853 \\
(1.388)\end{array}$ & $\begin{array}{l}-0.526 \\
(0.811)\end{array}$ & $\begin{array}{l}-0.235 \\
(1.396)\end{array}$ & & & \\
\hline Observations & 795 & 795 & 795 & 795 & 795 & 795 & 619 & 619 & 619 \\
\hline
\end{tabular}

Notes: Logistic regression results for human trafficking vulnerability and their standard errors in parentheses. Columns 1-3 are traditional logistic estimates, Columns 4-6 apply the rare events correction and Columns 7-9 are from a conditional logistic model with village-level fixed effects. Standard errors are heteroskedasticity robust and clustered by village. ${ }^{*}$ denotes significance at the $10 \%$ level, ${ }^{* *}$ at the $5 \%$ level and $* * *$ at the $1 \%$ level. 
Table 6: Bivariate probit with sample selection

\begin{tabular}{|c|c|c|c|}
\hline & $(1)$ & $(2)$ & $(3)$ \\
\hline $\begin{array}{l}\text { Trafficked } \\
\text { Within-household education difference }\end{array}$ & $\begin{array}{c}0.209^{* *} \\
(0.101)\end{array}$ & $\begin{array}{c}0.163 \\
(0.186)\end{array}$ & $\begin{array}{l}0.172^{*} \\
(0.102)\end{array}$ \\
\hline Average household education & $\begin{array}{r}-0.179^{*} \\
(0.097)\end{array}$ & $\begin{array}{c}-0.276^{* * *} \\
(0.105)\end{array}$ & $\begin{array}{c}-0.260^{* *} \\
(0.103)\end{array}$ \\
\hline Household income per person & $\begin{array}{c}-0.000^{*} \\
(0.000)\end{array}$ & & $\begin{array}{c}-0.000^{*} \\
(0.000)\end{array}$ \\
\hline Log monthly income & $\begin{array}{c}0.018 \\
(0.020)\end{array}$ & $\begin{array}{l}-0.011 \\
(0.015)\end{array}$ & \\
\hline Married & $\begin{array}{l}-0.101 \\
(0.149)\end{array}$ & & $\begin{array}{c}0.103 \\
(0.152)\end{array}$ \\
\hline Gender $(1=$ male $)$ & $\begin{array}{c}0.035 \\
(0.141)\end{array}$ & $\begin{array}{c}0.033 \\
(0.153)\end{array}$ & $\begin{array}{c}0.028 \\
(0.149)\end{array}$ \\
\hline Household size & & $\begin{array}{l}-0.048 \\
(0.070)\end{array}$ & $\begin{array}{l}-0.040 \\
(0.047)\end{array}$ \\
\hline Total children in household & & $\begin{array}{l}-0.240 \\
(0.173)\end{array}$ & $\begin{array}{c}-0.273^{* *} \\
(0.122)\end{array}$ \\
\hline Age & & $\begin{array}{l}-0.005 \\
(0.010)\end{array}$ & $\begin{array}{l}-0.009 \\
(0.007)\end{array}$ \\
\hline $\begin{array}{l}\text { Migrant } \\
\text { Within-household education difference }\end{array}$ & $\begin{array}{c}0.289^{* * *} \\
(0.030)\end{array}$ & $\begin{array}{c}0.371^{* * *} \\
(0.028)\end{array}$ & $\begin{array}{c}0.231^{* * *} \\
(0.031)\end{array}$ \\
\hline Average household education & $\begin{array}{c}0.049 \\
(0.031)\end{array}$ & $\begin{array}{l}-0.044 \\
(0.033)\end{array}$ & $\begin{array}{l}-0.017 \\
(0.035)\end{array}$ \\
\hline Household income per person & $\begin{array}{c}0.000 \\
(0.000)\end{array}$ & & $\begin{array}{c}0.000 \\
(0.000)\end{array}$ \\
\hline Percentage of household employed & $\begin{array}{c}-0.594^{* * *} \\
(0.163)\end{array}$ & $\begin{array}{c}0.143 \\
(0.167)\end{array}$ & $\begin{array}{c}-1.114^{* * *} \\
(0.181)\end{array}$ \\
\hline Employed & $\begin{array}{c}1.443^{* * *} \\
(0.094)\end{array}$ & & $\begin{array}{c}1.524^{* * *} \\
(0.107)\end{array}$ \\
\hline Married & $\begin{array}{c}-0.555^{* * *} \\
(0.065)\end{array}$ & $\begin{array}{l}-0.069 \\
(0.074)\end{array}$ & $\begin{array}{c}-0.366^{* * *} \\
(0.075)\end{array}$ \\
\hline Gender $(1=$ male $)$ & $\begin{array}{c}-0.045 \\
(0.059)\end{array}$ & $\begin{array}{l}-0.007 \\
(0.057)\end{array}$ & $\begin{array}{c}-0.042 \\
(0.060)\end{array}$ \\
\hline Household size & & $\begin{array}{c}0.101^{* * *} \\
(0.018)\end{array}$ & $\begin{array}{c}0.110^{* * *} \\
(0.019)\end{array}$ \\
\hline Total children in household & & $\begin{array}{c}-0.325^{* * *} \\
(0.045)\end{array}$ & $\begin{array}{c}-0.338^{* * *} \\
(0.048)\end{array}$ \\
\hline Age & & $\begin{array}{c}-0.011^{* * *} \\
(0.002)\end{array}$ & $\begin{array}{c}-0.016^{* * *} \\
(0.003)\end{array}$ \\
\hline rho & 0.59 & 0.24 & 0.47 \\
\hline
\end{tabular}

Notes: Bivariate probit estimates of migration and trafficking. Standard errors are clustered by village. * denotes significance at the $10 \%$ level, $* *$ at the $5 \%$ level and ${ }^{* * *}$ at the $1 \%$ level. 
Table 7: Anchoring vignettes

\begin{tabular}{lccccc}
\hline & All & Non-migrants & Migrants & Trafficked & Former migrant \\
\hline Correct response - vignette 1 & 0.73 & 0.74 & 0.72 & 0.59 & 0.70 \\
& $(0.44)$ & $(0.44)$ & $(0.45)$ & $(0.50)$ & $(0.46)$ \\
Correct response - vignette 2 & 0.40 & 0.38 & 0.41 & 0.56 & 0.56 \\
& $(0.49)$ & $(0.49)$ & $(0.49)$ & $(0.51)$ & $(0.50)$ \\
Correct response - vignette 3 & 0.72 & 0.77 & 0.67 & 0.67 & 0.64 \\
& $(0.45)$ & $(0.43)$ & $(0.47)$ & $(0.48)$ & $(0.48)$ \\
Number of correct vignette responses & 1.84 & 1.89 & 1.79 & 1.81 & 1.85 \\
& $(0.57)$ & $(0.55)$ & $(0.60)$ & $(0.62)$ & $(0.76)$ \\
\hline Cronbach's $\alpha$ & 0.667 & 0.506 & 0.694 & 0.818 & 0.439 \\
Observations & 492 & 90 & 402 & 27 & 54 \\
\hline
\end{tabular}

Notes: Correct responses to three anchoring vignettes by various groups. Each row reports the mean correct and the standard deviation below in parentheses. Probability weights have been applied in Column 1 to correct for the oversampling of migrant households. Cronbach's alpha is reported as a measure of the internal consistency of the responses. 
Table 8: Vignette-adjusted logistic regressions

\begin{tabular}{|c|c|c|c|c|c|c|c|}
\hline & $\begin{array}{l}(1) \\
\text { All }\end{array}$ & $\begin{array}{c}(2) \\
\text { Vignette } 1 \text { correct }\end{array}$ & $\begin{array}{c}(3) \\
\text { Vignette } 2 \text { correct }\end{array}$ & $\begin{array}{c}(4) \\
\text { Vignette } 3 \text { correct }\end{array}$ & $\begin{array}{l}(5) \\
1 \text { correct response }\end{array}$ & $\begin{array}{c}(6) \\
2 \text { correct responses }\end{array}$ & $\begin{array}{l}(7) \\
3 \text { correct responses }\end{array}$ \\
\hline $\begin{array}{l}\text { Trafficked } \\
\text { Within-household education difference }\end{array}$ & $\begin{array}{c}0.523^{* * *} \\
(0.155)\end{array}$ & $\begin{array}{l}0.772^{*} \\
(0.317)\end{array}$ & $\begin{array}{l}0.366^{*} \\
(0.170)\end{array}$ & $\begin{array}{c}0.591 \\
(0.383)\end{array}$ & $\begin{array}{c}0.407^{* * *} \\
(0.102)\end{array}$ & $\begin{array}{c}0.574 \\
(0.344)\end{array}$ & \\
\hline Average household education & $\begin{array}{l}-0.756 \\
(0.438)\end{array}$ & $\begin{array}{l}-1.324 \\
(0.950)\end{array}$ & $\begin{array}{l}-0.296 \\
(0.244)\end{array}$ & $\begin{array}{l}-1.410 \\
(1.002)\end{array}$ & $\begin{array}{l}-0.185 \\
(0.106)\end{array}$ & $\begin{array}{l}-1.468 \\
(0.983)\end{array}$ & \\
\hline Household income per person & $\begin{array}{l}-1.77 \mathrm{e}-07 \\
(1.39 \mathrm{e}-07)\end{array}$ & $\begin{array}{l}-9.84 \mathrm{e}-09 \\
(4.59 \mathrm{e}-08)\end{array}$ & $\begin{array}{c}-5.58 \mathrm{e}-07^{*} \\
(2.37 \mathrm{e}-07)\end{array}$ & $\begin{array}{l}-3.95 \mathrm{e}-08 \\
(8.65 \mathrm{e}-08)\end{array}$ & $\begin{array}{c}-9.78 \mathrm{e}-07^{* * *} \\
(2.85 \mathrm{e}-07)\end{array}$ & $\begin{array}{c}4.98 \mathrm{e}-08 \\
(5.64 \mathrm{e}-08)\end{array}$ & \\
\hline Percentage of household employed & $\begin{array}{c}0.795 \\
(1.464)\end{array}$ & $\begin{array}{l}-0.180 \\
(1.666)\end{array}$ & $\begin{array}{c}2.497 \\
(1.881)\end{array}$ & $\begin{array}{l}-0.388 \\
(1.741)\end{array}$ & $\begin{array}{l}4.396^{*} \\
(1.943)\end{array}$ & $\begin{array}{l}-1.753 \\
(1.855)\end{array}$ & \\
\hline Employed & $\begin{array}{c}0.890 \\
(0.528)\end{array}$ & $\begin{array}{c}0.732 \\
(0.814)\end{array}$ & $\begin{array}{l}1.756^{*} \\
(0.775)\end{array}$ & $\begin{array}{c}0.940 \\
(0.850)\end{array}$ & $\begin{array}{c}0.653 \\
(0.888)\end{array}$ & $\begin{array}{c}0.872 \\
(0.901)\end{array}$ & \\
\hline Married & $\begin{array}{c}0.205 \\
(0.305)\end{array}$ & $\begin{array}{c}0.105 \\
(0.354)\end{array}$ & $\begin{array}{l}-0.181 \\
(0.397)\end{array}$ & $\begin{array}{l}-0.209 \\
(0.474)\end{array}$ & $\begin{array}{c}0.676 \\
(0.433)\end{array}$ & $\begin{array}{c}0.409 \\
(0.399)\end{array}$ & \\
\hline Gender $(1=$ male $)$ & $\begin{array}{l}0.0418 \\
(0.337)\end{array}$ & $\begin{array}{l}-0.250 \\
(0.739)\end{array}$ & $\begin{array}{l}-0.0211 \\
(0.582)\end{array}$ & $\begin{array}{c}0.237 \\
(0.462)\end{array}$ & $\begin{array}{c}-0.0733 \\
(0.803)\end{array}$ & $\begin{array}{c}-0.0462 \\
(0.612)\end{array}$ & \\
\hline Household size & $\begin{array}{c}-0.0360 \\
(0.113)\end{array}$ & $\begin{array}{l}-0.110 \\
(0.190)\end{array}$ & $\begin{array}{l}0.0494 \\
(0.125)\end{array}$ & $\begin{array}{c}-0.0458 \\
(0.187)\end{array}$ & $\begin{array}{l}0.0233 \\
(0.196)\end{array}$ & $\begin{array}{l}0.0687 \\
(0.145)\end{array}$ & \\
\hline Total children in household & $\begin{array}{c}-0.691^{* *} \\
(0.258)\end{array}$ & $\begin{array}{c}-0.580^{*} \\
(0.293)\end{array}$ & $\begin{array}{c}-0.953^{* *} \\
(0.355)\end{array}$ & $\begin{array}{l}-0.552 \\
(0.300)\end{array}$ & $\begin{array}{c}-0.900^{* *} \\
(0.309)\end{array}$ & $\begin{array}{c}-0.932^{* *} \\
(0.361)\end{array}$ & \\
\hline Age & $\begin{array}{c}-0.0265^{*} \\
(0.0107)\end{array}$ & $\begin{array}{l}-0.0229^{*} \\
(0.00958)\end{array}$ & $\begin{array}{c}-0.0240 \\
(0.0191)\end{array}$ & $\begin{array}{c}-0.0271 \\
(0.0162)\end{array}$ & $\begin{array}{c}-0.0314 \\
(0.0198)\end{array}$ & $\begin{array}{c}-0.0302^{* *} \\
(0.0110)\end{array}$ & \\
\hline Constant & $\begin{array}{c}-1.939 \\
(1.133) \\
\end{array}$ & $\begin{array}{c}0.147 \\
(1.325) \\
\end{array}$ & $\begin{array}{c}-4.543^{*} \\
(2.057) \\
\end{array}$ & $\begin{array}{c}0.151 \\
(1.433) \\
\end{array}$ & $\begin{array}{c}-5.120^{* * *} \\
(0.951) \\
\end{array}$ & $\begin{array}{c}0.900 \\
(1.679) \\
\end{array}$ & \\
\hline Observations & 2394 & 1761 & 961 & 1651 & 659 & 1500 & 36 \\
\hline
\end{tabular}

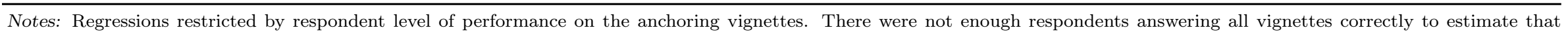
specification. 
Table 9: Reason believe trafficked

\begin{tabular}{lcc}
\hline & Frequency & Percent \\
\hline Lack of contact & 38 & 100.0 \\
Stopped sending remittances & 5 & 13.2 \\
Victim told respondent & 14 & 36.8 \\
Family or friends told respondent & 1 & 2.6 \\
Law enforcement officer told respondent & 0 & 0.0 \\
Rumor & 0 & 0.0 \\
Other reason & 6 & 15.8 \\
\hline
\end{tabular}

Notes: Reported reason they believe household member was trafficked. Percentages do not sum to 100, as some respondents reported multiple reasons. 
Table 10: Principal component regressions

\begin{tabular}{|c|c|c|c|c|c|c|c|c|c|}
\hline & \multicolumn{3}{|c|}{ Logit } & \multicolumn{3}{|c|}{ RE-Adjusted Logit } & \multicolumn{3}{|c|}{ Conditional Logit } \\
\hline & $(1)$ & $(2)$ & $(3)$ & $(4)$ & $(5)$ & (6) & $(7)$ & $(8)$ & $(9)$ \\
\hline Average household education & $\begin{array}{c}-0.651^{* *} \\
(0.280)\end{array}$ & $\begin{array}{c}-0.686^{* * *} \\
(0.260)\end{array}$ & $\begin{array}{c}-0.663^{* *} \\
(0.264)\end{array}$ & $\begin{array}{c}-0.605^{* *} \\
(0.277)\end{array}$ & $\begin{array}{c}-0.645^{* *} \\
(0.256)\end{array}$ & $\begin{array}{c}-0.618^{* *} \\
(0.260)\end{array}$ & $\begin{array}{c}-0.658^{*} \\
(0.368)\end{array}$ & $\begin{array}{c}-0.739^{* *} \\
(0.294)\end{array}$ & $\begin{array}{c}-0.710^{* *} \\
(0.320)\end{array}$ \\
\hline Household income per person & $\begin{array}{l}-0.000 \\
(0.000)\end{array}$ & & $\begin{array}{l}-0.000 \\
(0.000)\end{array}$ & $\begin{array}{l}-0.000 \\
(0.000)\end{array}$ & & $\begin{array}{l}-0.000 \\
(0.000)\end{array}$ & $\begin{array}{l}-0.000 \\
(0.000)\end{array}$ & & $\begin{array}{l}-0.000 \\
(0.000)\end{array}$ \\
\hline Percentage of household employed & $\begin{array}{c}0.482 \\
(1.002)\end{array}$ & & $\begin{array}{c}0.480 \\
(0.902)\end{array}$ & $\begin{array}{c}0.348 \\
(0.992)\end{array}$ & & $\begin{array}{c}0.308 \\
(0.888)\end{array}$ & $\begin{array}{c}1.460 \\
(1.012)\end{array}$ & & $\begin{array}{c}1.149 \\
(1.304)\end{array}$ \\
\hline First principal component & $\begin{array}{l}-0.197 \\
(0.186)\end{array}$ & $\begin{array}{l}-0.199 \\
(0.206)\end{array}$ & $\begin{array}{l}-0.202 \\
(0.206)\end{array}$ & $\begin{array}{l}-0.195 \\
(0.184)\end{array}$ & $\begin{array}{l}-0.197 \\
(0.203)\end{array}$ & $\begin{array}{l}-0.195 \\
(0.203)\end{array}$ & $\begin{array}{c}0.213 \\
(0.229)\end{array}$ & $\begin{array}{c}0.194 \\
(0.239)\end{array}$ & $\begin{array}{c}0.234 \\
(0.247)\end{array}$ \\
\hline Household size & & $\begin{array}{c}0.056 \\
(0.210)\end{array}$ & $\begin{array}{c}0.051 \\
(0.221)\end{array}$ & & $\begin{array}{c}0.060 \\
(0.208)\end{array}$ & $\begin{array}{c}0.061 \\
(0.217)\end{array}$ & & $\begin{array}{c}0.243 \\
(0.174)\end{array}$ & $\begin{array}{c}0.211 \\
(0.194)\end{array}$ \\
\hline Total children in household & & $\begin{array}{c}0.053 \\
(0.536)\end{array}$ & $\begin{array}{c}0.099 \\
(0.565)\end{array}$ & & $\begin{array}{c}0.093 \\
(0.530)\end{array}$ & $\begin{array}{c}0.117 \\
(0.555)\end{array}$ & & $\begin{array}{l}-0.141 \\
(0.401)\end{array}$ & $\begin{array}{l}-0.066 \\
(0.415)\end{array}$ \\
\hline Average households age & & $\begin{array}{c}0.022 \\
(0.030)\end{array}$ & $\begin{array}{c}0.025 \\
(0.028)\end{array}$ & & $\begin{array}{c}0.025 \\
(0.030)\end{array}$ & $\begin{array}{c}0.027 \\
(0.028)\end{array}$ & & $\begin{array}{c}0.013 \\
(0.034)\end{array}$ & $\begin{array}{c}0.019 \\
(0.035)\end{array}$ \\
\hline Constant & $\begin{array}{l}-1.512 \\
(1.106)\end{array}$ & $\begin{array}{c}-2.318^{* * *} \\
(0.721)\end{array}$ & $\begin{array}{c}-2.634^{* * *} \\
(0.715)\end{array}$ & $\begin{array}{l}-1.522 \\
(1.094)\end{array}$ & $\begin{array}{c}-2.421^{* * *} \\
(0.713)\end{array}$ & $\begin{array}{c}-2.660^{* * *} \\
(0.703)\end{array}$ & & & \\
\hline Observations & 487 & 487 & 487 & 487 & 487 & 487 & 374 & 374 & 374 \\
\hline
\end{tabular}

Notes: Household-level regressions incorporating the predicted first principal component score of the anchoring vignette responses as an explanatory variable. 
Table 11: Consequences of losing remittances

\begin{tabular}{lcc}
\hline & Frequency & Percent \\
\hline Do nothing differently & 51 & 6.42 \\
Reduce durable expenditures & 18 & 2.26 \\
Reduce non-durable expenditures & 94 & 11.82 \\
Reduce service expenditures & 91 & 11.45 \\
Remove students from school & 21 & 2.64 \\
Current workers work more & 89 & 11.19 \\
Another member takes a new job & 94 & 11.82 \\
Increase credit/loan use & 444 & 55.85 \\
\hline
\end{tabular}

Notes: Reported consquences of losing remittances. Percentages do not sum to 100, as some respondents reported multiple reasons. 